\title{
THE ROLE OF CORPORATE SOCIAL RESPONSIBILITY IN DEVELOPMENT OF COMMUNICATION WITH EXTERNAL STAKEHOLDERS AND ENVIRONMENTAL PROTECTION - AN EXAMPLE OF A TELECOMMUNICATIONS COMPANY
}

\author{
Wiesław SZOPIŃSKI ${ }^{1}$, Marta KAWA ${ }^{2}$, Tomasz SURMACZ ${ }^{3 *}$ \\ ${ }^{1}$ University of Rzeszów, Rzeszów; wszopin@ur.edu.pl, ORCID: 0000-0003-2524-440X \\ ${ }^{2}$ University of Rzeszów, Rzeszów; marka@ur.edu.pl, ORCID: 0000-0002-3023-9085 \\ ${ }^{3}$ University of Rzeszów, Rzeszów; toms@ur.edu.pl, ORCID: 0000-0001-7086-1322 \\ * Correspondence author
}

Purpose: The concept of CSR is one of the most important topics from the point of view of both scientific research and companies' actions. Although corporate social responsibility seems to be common practice, however in many cases, these are often one-time actions aimed at building firms' image. The paper tries to look at this issue from a perspective of a telecommunications company.

Design/methodology/approach: Secondary sources of information were used as well primary ones, obtained by the means of direct interviews conducted in a company providing telecommunication services, using an independently prepared, unstructured questionnaire as the research tool. The data obtained was analyzed using the inductive-deductive method.

Findings: The CSR initiatives undertaken by the studied company proves that it develops good, long-term relations with its stakeholders such as suppliers and business partners, clients as well as the local government. The corporate social responsibility is incorporated in company's organizational culture and it cannot be treated as one-time, ad-hoc events which is quite common for other companies.

Originality/value: The analyzed company was not previously studied in terms of CSR activities. The paper can be useful for stakeholders, especially the local government as it can see the firm's strong commitment to the development of the social, the economic and the natural environment of the region.

Keywords: CSR, enterprise, external stakeholders, natural environment.

Category of the paper: Case study. 


\section{Introduction}

Intensive development of corporate social responsibility in enterprises had begun in developed countries in the 1960 s as a result of the impact of two social movements: the consumer movement and the environmental movement (Sawicki, 2007). The idea of corporate social responsibility encompasses numerous issues that are of interest with relation to many scientific fields, i.e. economics, management, philosophy, and ethics, and thus its various elements have been emphasized in science, depending on the approach used (Smith, Lenssen, 2009). In its the definition of CSR, the World Business Council for Sustainable Development indicates the significance of sustainable economic development as an important factor determining the quality of employees' and local communities' life (Kietliński et al., 2005). Referring to sustainable economic development, the definition adopted in 2011 by the European Commission emphasizes that CSR is a concept according to which economic entities should take into account both the social and the environmental aspects, taking this way responsibility for the impact of their activity on the external environment (Odnowiona strategia ..., 2011).

Corporate social responsibility constitutes an integral part of the operation strategy in many companies both in Poland (Płoszajski, 2015) and worldwide (Asemah et al., 2013), bringing many benefits to the companies themselves as well as to their internal and external stakeholders. These benefits include: improvement of company image, increased employee satisfaction and greater customer loyalty. Mourougan (2015) underlines the fact that enterprises implementing CSR are more valued by investors and financiers, who consider such companies as wellmanaged entities that care for their value. Bartkowiak (2011), on the other hand, accentuates the fact that CSR is one of the methods used to gain competitive advantage on the market.

One such CSR tool is public awareness campaigns. Social campaign activity is meant to draw attention to a specific social problem, using the marketing experience of a given enterprise (Łukasiewicz-Kamińska, 2011). The decision to create public awareness campaigns must be considered in terms of the company's financial capabilities. Such activity can quite effectively improve a given company's competitive position and reputation. The benefits that social campaigns bring for the community, on the other hand, depend on the topic they address. They can influence economic or social awareness, or draw attention to the education-, the safety- or the health-related issues in local communities. As part of their social campaign activities, companies often come up with ideas for competitions or programs and, offering something in return, encourage the public to look at the social problem addressed creatively. Such activities bring results in the form of increased reach and recognition as well as new potential customers (Leoński, 2016). 


\section{Research methodology}

To implement the topic adopted, subject-related literature was used. Primary sources of information were used as well, obtained by the means of direct interviews conducted in a company providing telecommunication services ${ }^{1}$, using an independently prepared, unstructured questionnaire, the so-called list of questions, as the research tool. The data obtained was analyzed using the inductive-deductive method.

\section{Research results}

The enterprise surveyed provides telecommunication services. It has been operating on the market for over a hundred years. In the last thirty years, it has undergone ownership and organizational transformation. Since December 2013, it has operated as a joint-stock company. Its potential entails good technical structure, which allows provision of a wide range of services, especially mobile and fixed-line telephony and data transmission. Due to the very dynamic changes taking place in telecommunication, in order to maintain its position on the competitive market, it constantly adjusts its activity to the increasing demands of the service recipients. It has, inter alia, prepared a special offer for customers who are particularly sensitive to prices, which is distinguishable by its transparent contract terms, low prices and online sale.

Maintenance of the company's strong market position is also fostered by the system of corporate social responsibility that has been implemented for several years. As part of this system, the management board has been developing partner marketing, which consists in the shaping of long-term, good relations with both the employees, i.e. internal stakeholders, and the external stakeholders. The latter include individual and institutional service recipients, who deserve special attention, since bot the enterprises as well as the local and regional community are inextricably interlinked and, according to, inter alia, Olejniczak (2013), constitute the social aspect of the CSR idea. In this respect, the types of the surveyed company's stakeholders are presented in Figure 1.

\footnotetext{
${ }^{1}$ The permission to publish the research results was conditioned by the company's anonymity.
} 


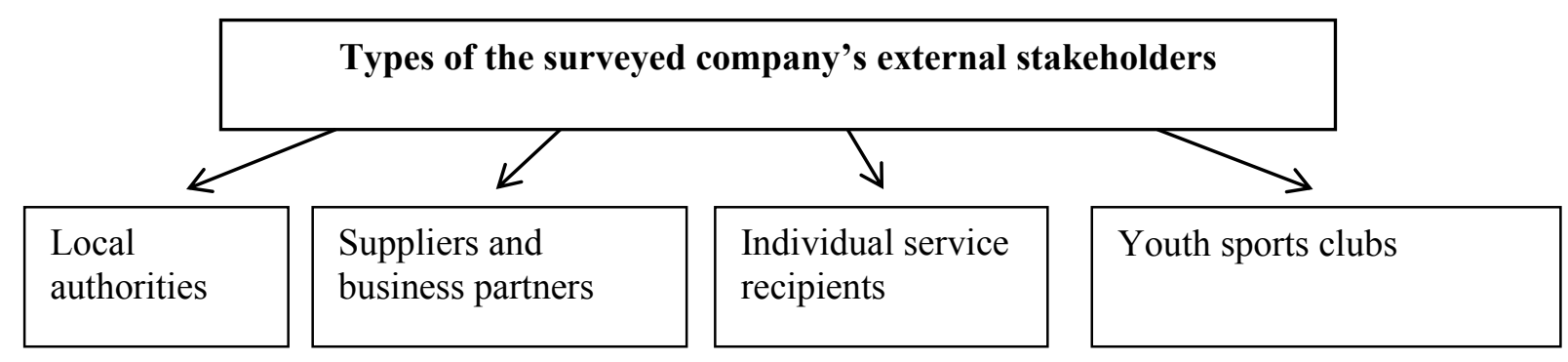

Figure 1. Types of the surveyed telecommunications company's stakeholders. Source: own elaboration based on the empirical study.

The types of the surveyed company's external stakeholders, whom it has developed lasting relationships with by implementing a diversified scope of activities, vary. Its cooperation with the local authorities is aimed at joint problem solving, in terms to the flow of information and improvement of the telecommunication infrastructure. One example here is the construction of a fiber-optic network that provides the voivodeship residents with access to high-speed Internet, with speeds of up to $300 \mathrm{Mb} / \mathrm{s}$, as well as to HD quality TV channels and telephony services. The enterprise allocated its own funds for this network implementation, while the local government, a party to the contract, limited the necessary formalities to a minimum and supported the company's promotional activity. The company also participated in the educational activities carried out by the local government, which were meant to inform the residents about the possibility of using the high-speed fiber optic network for work, entertainment and individual interests.

The company's external stakeholders also include suppliers and business partners. Lasting business relationships are established upon long-term contracts with representatives of those companies, which are based on transparent principles of cooperation, providing both sides with stability and development opportunities. The company also runs a periodic supplier evaluation program. The long-term contracts concluded with the suppliers account for over $90 \%$ of all the contracts, which favors development of a socially responsible supply chain.

Other external stakeholders are individual clients, who are, inter alia, provided with knowledge through modern forms of education for children, youth and residents, as to strengthen the digital competences of those acquiring knowledge, especially those in smaller towns, as well as to build communities, using the Internet and new technologies. With regard to childhood education, the following programs deserve attention:

- The digital education program dedicated for primary schools and implemented at school common rooms. Its goal is to provide digital literacy to the youngest students. Learning takes place through play, owing to the fact that the program is based on educational games. 
- The "sounds of dreams" [PL: "dzwięki marzeń"] program, which aims to support the development of deaf children.

- The "educational island for young patients" ["edukacyjna wyspa dla małych pacjentów"] program, addressed to children staying in hospitals, to make this stay more friendly and, at the same time, to create multimedia spots for learning, play and development of digital competences.

- The program developed for children aged 9 to 12 , which is meant to teach the principles of programming and the basics of robotics. Children learn programming in practice and develop skills of logical thinking, teamwork and creativity.

- The "safety here and there" ["bezpiecznie tu i tam"] program, which aims to prepare the youngest children for safe functioning in the virtual world of the Internet.

The company also has been implementing such programs for young people and adults:

- The "join in wisely" ["włącz się z głową"] program encouraging young people to use the Internet and new technologies wisely, as to learn about the country, the world and the cultures of different nations.

- The educational platform that provides access to high-quality education in mathematics, physics, programming, biology and history via the Internet.

- The "virtual museums" ["wirtualne muzea"] program which allows familiarization with museum collections from around the world.

- The "acquittance with passions" ["spotkanie z pasjami"] program developed for social activation of seniors.

Additionally, a corporate volunteering program functions in the telecommunications company surveyed. It entails a group of employees who, by being socially active, act with clients in mind, noticing and respecting their needs, as well as engage in new pro-consumer projects.

It should be underlined that owing to the above-presented programs, the company has contributed to the provision of Internet access for residents, especially in small towns, to the dissemination of new digital competences among local communities, to the acquisition of communication skills and competences that allow residents to deal with everyday matters via the Internet, as well as to the increase of knowledge on cyberspace safety.

The company has also been involved in the promotion of healthy and sustainable child and youth development, by supporting local communities in the Subcarpathia voivodeship. As such, it participates in the national project of sponsoring children and youth sports teams in five disciplines, i.e. football, volleyball, basketball, handball and athletics. Each team has been equipped with good-class sports equipment and training clothes. Moreover, specially developed training programs have been made available via an Internet platform. It should be emphasized that, as indicated by Grzybek (2005), activities aimed at sports and recreation development, including sports club sponsorship, require significant financial outlays, therefore this form of 
CSR implementation is most commonly chosen by large companies and targets well-known sports clubs. In the case analyzed, however, such activity benefiting local communities, activating children, youth, their parents, teachers and coaches to jointly act for comprehensive development of sport, is a completely new phenomenon.

While implementing corporate social responsibility with respect to the local and regional community, the surveyed company's management has been paying equal attention to environmental protection.

The scope of the environmental protection activities carried out by the company surveyed as part of CSR is presented in Figure 2.

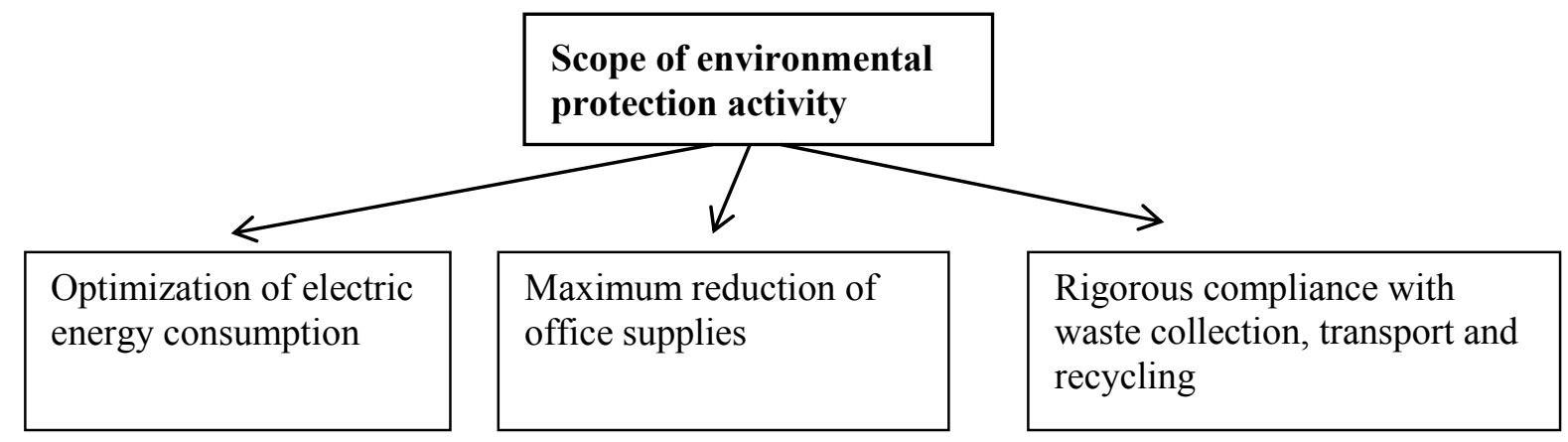

Figure 2. The company's pro-ecological activity. Source: own elaboration based on the empirical study.

As Figure 2 shows, the company's activities aimed at natural environment protection concern three very important areas that are associated with the functioning of the enterprise. While paying attention to the specificity of the industry and the need to expand the telecommunication infrastructure, which is associated with an increase in electricity demand a factor that is very unfavorable for the environment, the company has been taking steps to optimize its energy consumption. These activities concern, inter alia, the following:

- records and analysis of energy consumption, based on detailed invoice data, and the use of intelligent metering devices, owing to which the amount of the energy consumed can be precisely assessed online, allowing quick reaction when energy consumption is too high;

- development of energy consumption models, broken down into network domains, types of devices, objects determining energy consumption in individual ports;

- development of an energy management model describing the main functions, responsibilities and processes, in terms of savings initiatives, facility management, the energy consumption growth balance resulting from network evolution, as well as verification of energy supplier invoice correctness;

- optimization of the technical network structure;

- replacement of older-generation devices with more modern, energy-saving ones;

- modernization of the cooling systems;

- replacement of traditional and halogen lighting in showrooms with LED lighting;

- insulation of existing buildings, in order to reduce heat loss. 
The employees using passenger cars to perform their official tasks take part in specialist eco-driving training courses, in order to reduce fuel consumption costs.

As a way to reduce consumption of office supplies, especially paper, computer applications are used to keep attendance lists, settle business trip expenses and plan vacation time. E-documents are used for contacts with suppliers, which allows placement of electronic placement of orders, confirmation of courier deliveries and invoice archiving.

As a provider of ICT services, the company has faced the problem of vast waste generation, a significant part of which is used mobile phones, which are hazardous waste. The company has therefore developed a program of used ICT equipment buyback and utilization. Owing to the high CSR awareness on the part of the company's management, only companies that take full responsibility for further handling of the waste received, from its collection and transport to recovery or disposal, are selected. These companies are obliged to present documentation regarding individual stages of hazardous waste utilization.

\section{Discussion}

The above-presented description of the surveyed company's CSR initiatives proves that the company undertakes many activities with respect to its external stakeholders, the aim of which is to develop good long-term relations with its suppliers and business partners, its service recipients, as well as the local government and youth sports clubs.

Prosocial involvement deserves the term used by Buczkowski et al. (2016) - the "license to act" ["licencja na działanie"]. This term is understood as community's acceptance for the activity undertaken by a specific company for the benefit of the local environment, based on mutual relations, which the company surveyed is a positive example of.

The company's cooperation with the local authorities results from the nature of the industry in which it operates. It should be emphasized that these relations have been very successful for many years. It is beneficial for both partners, as the company pays taxes and thus is a source of income for the local government, which in turn tries to build the company's good image. Adamczyk (2009) states that a positive image is a necessary condition for stable long-term company development and operation on the market. Fonfara (1999) and Krzysztofek (2014), on the other hand, believe that a company's good image is one of the most valuable elements constituting the intangible value of any economic entity.

The company's investment in the fiber-optic network has contributed to the development of infrastructure, and thus to the increase in the economic potential of the Subcarpathia voivodeship as well as to the development of information society, which has also been supported by educational activities, the importance of which is underlined, inter alia, by Kluszczyński (2011). 
In terms of the company surveyed, the programs developed for and adapted to different client age groups, including deaf children or the children staying in hospitals, deserve to be highlighted, which proves that the company cares about each service recipient and shows humane treatment of all citizens.

The youth sports club sponsorship allows children and young adults to develop their sports passions and, at the same time, teaches them the skills of cooperation and fair competition. These principles are very important in the conduct of every human being, not only in sports but also in professional and social life.

The CSR activities carried out for the benefit of local and regional communities stimulate the resolution of economic, social and environmental problems. The benefits he companies operating in this way enjoy are not immediate (e.g. educational support), but they bring effects in the long run. In this type of activity, the social, environmental and business goals are balanced, as indicated by e.g. Gołaszewska-Koczan (2009).

All the rational environmental-protection undertakings on the part of the entity surveyed should be assessed positively. It turns out that the company's management takes this important issue very seriously, which is crucial for today's and future generations.

\section{Conclusions}

Implementation of corporate social responsibility oriented at the shaping of positive relations with external stakeholders is very advanced in the company surveyed and applies to every entity which the company has a relationship with.

The range of the activities carried out by the company, including good relations with all stakeholders, is very broad and pertains to the development of infrastructure, education, and environmental protection, which proves its strong commitment to the development of the social, the economic and the natural environment of the Subcarpathia voivodeship.

The multitude of the environmental-protection activities undertaken by the company results in comprehensive application of the corporate social responsibility principles with respect to the natural environment.

The company's implementation of corporate social responsibility constitutes an element of a safe strategy, the role of which is, inter alia, to counteract various types of threats that have been emerging along with the dynamic development of the industry in which it operates. 


\section{References}

1. A renewed EU strategy for 2011-2014 for Corporate Social Responsibility. Communication from the Commission to the European Parliament, the Council, the European Economic and Social Committee and the Committee of the Regions. COM (2011) 681 final, Brussels.

2. Adamczyk, J. (2009). Społeczna odpowiedzialność jako mechanizm nadzoru korporacyjnego. Łódź: Łódzkie Towarzystwo Naukowe.

3. Asemah, E., Okpanachi, R., Edegoh, L. (2013). Business advantages of corporate social responsibility practice: a critical review. New Media and Mass Communication, Vol. 18.

4. Bartkowiak, G. (2011). Społeczna odpowiedzialność biznesu $w$ aspekcie teoretycznym i empirycznym. Warsaw: Difin.

5. Buczkowski, B., Dorożyński, T., Kuna-Marszałek, A., Serwach, T., Wieloch, J. (2016). Społeczna odpowiedzialność biznesu. Studia przypadków firm międzynarodowych. Łódź: Wydawnictwo Uniwersytetu Łódzkiego.

6. Fonfara, K. (1999). Marketing partnerski na rynku przedsiębiorstw. Warsaw: PWE.

7. Gołaszewska-Kaczan, U. (2009). Zaangażowanie społeczne przedsiębiorstwa. Białystok: Uniwersytet w Białymstoku.

8. Grzybek, M. (2014). Zakres stosowania społecznej odpowiedzialności biznesu w firmach małej i średniej skali. Marketing i Rynek, No. 8.

9. Kietliński, K., Reyes, V.M., Oleksyn, T. (2005). Etyka w biznesie i zarządzaniu. Cracow: Oficyna Ekonomiczna.

10. Kluszczyński, R. (2001). Społeczeństwo informacyjne: cyberkultura, sztuka multimediów. Cracow: Rabid.

11. Krzysztofek, A. (2014). Społeczna odpowiedzialność jako mechanizm nadzoru korporacyjnego. Łódź: Łódzkie Towarzystwo Naukowe.

12. Leoński, W. (2016). Narzędzia społecznej odpowiedzialności biznesu a wielkość przedsiębiorstwa, Studia Ekonomiczne. Zeszyty Naukowe Uniwersytetu Ekonomicznego w Katowicach, No. 254.

13. Łukasiewicz-Kamińska, A. (2011). Społeczna odpowiedzialność przedsiębiorstwa finansowego. Warsaw: Difin.

14. Mourougan, S. (2015). Corporate social responsibility for sustainable business. Journal of Business and Management, 17, 5, Vol. I.

15. Płoszajski, P. (ed.). (2015). Polscy dyrektorzy o społecznej odpowiedzialności biznesu. Warsaw: Wydawnictwo OpenLinks.

16. Sawicki, J. (2007). Marketing Nowej ery. Marketing i Rynek, No. 11.

17. Smith, N.C., Lenssen, G. (2009). Odpowiedzialność biznesu. Teoria i praktyka. Warsaw: Studio EMKA. 